\title{
Treasurer's Report
}

Taking off my Treasurer's hat and putting on my Materials Research Society member hat, I ask the MRS Treasurer, "What difference does the MRS budget make to me and to my travel budget? And when are we going to have the MRS Fall Meeting in the Bahamas?" Taking off that hat I answer, "The budget is important to your research as explained below; I'll have to get back to you on the Bahamas."

MRS is about meetings, first and foremost, but it is also about publications, public affairs, education, and lots of Society-mediated interactions between materials researchers. Assuredly, this activity and its behind-thescenes support cost money, which is raised through my fees and yours from our research budgets. While I do not calculate return on investment in my daily life and I bet you don't either, when I settle accounts after a week in San Francisco or Boston, the cost causes me to rethink the benefits of the trip.

My trip voucher to San Francisco was $\$ 2,300$, nearly half of which is for lodging. (I stay all week, but if I were to stay only one night the cost would still be at least $\$ 1,100$.) Registration is about $15 \%$ of my expenses while $5 \%$ is for Proceedings and Journal of Materials Research (JMR) renewal. Thus $20 \%(\$ 440)$ of my budget goes directly to MRS; an additional $46 \%(\$ 1,050)$ is affected by MRS-negotiated lodging rates. MRS practice therefore determines the disposition of two-thirds of my travel budget through firstorder effects.

Were we to hold our Spring Meeting outside of our traditional-if-difficult Easter time slot, the hotel rates would be some $18 \%$ higher, or $\$ 230$ in my budget. And if our registration were more typical of professional societies, say $\$ 425$ instead of $\$ 315$, I would pay an additional $\$ 110$. Adding first-order savings from the Fall and Spring Meetings, MRS economizing is worth about $\$ 700$ a year to me.

But what happens to the $\$ 440$ I sent directly to MRS this last spring? (See Table I.) Here's where important leverage for research dollar comes in, because for every $\$ 0.64$ I pay in these direct costs, another $\$ 0.36$ come in through exhibits, non-meeting dues, contributions, advertising, and symposium funding. In absolute numbers MRS annual operating revenues are $\$ 474$ per member for a total of $\$ 5,929$ thousand.

That combined $\$ 1.00$ gets ploughed back into the core businesses, especially support for meetings (see Figure 1). About a quarter is used to produce Proceedings, MRS Bulletin, and $J M R$, and a very important penny goes to awards and education. Two dimes defray direct meeting and symposium costs. A half-dollar goes to support the professional staff in MRS Headquarters and volunteers in governance who work to make MRS meetings among the best scientific meetings in the world. Herein lies the real return on my $\$ 0.64$ investment.

In 1998 , we actually spent $\$ 1.01$ ( $\$ 6,003$ thousand) for every dollar of operating revenue: The extra penny spent on initiatives approved by Council and the Executive Committee effectively came out of our cash flow, which is a ballast that ended the year at $\$ 0.21$.

A keener indicator of the Society's finances comes from the Consolidated Budget, which adds investments to the picture just described (see Tables I and II). Our revenue dollar

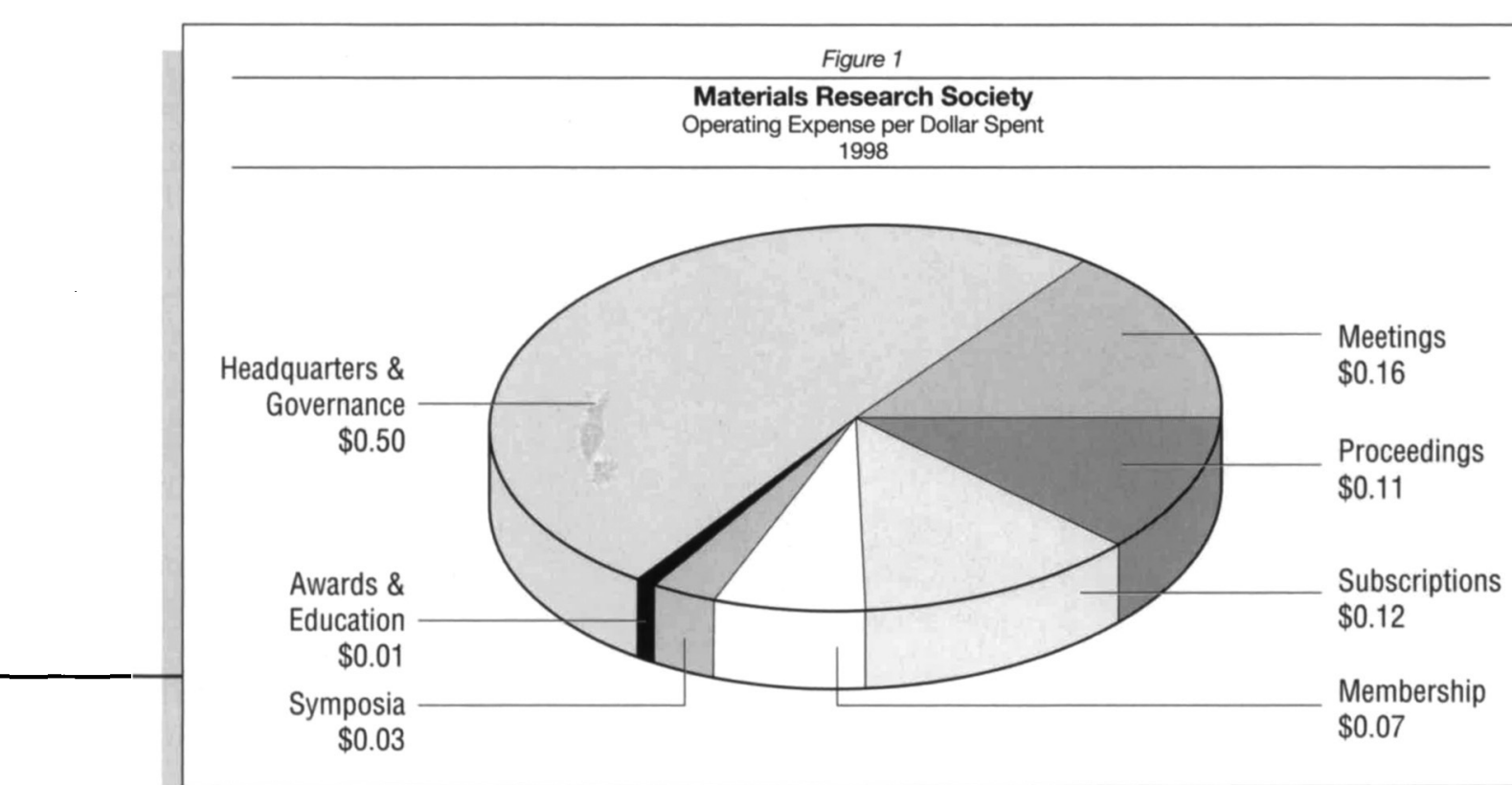


from Operations was augmented by $\$ 0.11$ earned by investments allowing the Society to finish the year with a net gain of $\$ 0.10$ on a Consolidated basis. The actual number was $\$ 381$ thousand or $\$ 30$ per member.

The 1999 budget has several important initiatives in meetings, publications, and education. The first two national-level MRS Workshops were held this summer in an important experiment to serve members with meetings better tailored to their needs. The Fall Meeting was sited in part in the Hynes Convention Center to simplify the notorious three-hotel meeting. Electronic Proceedings were tried for the first time in MRS, and the Journal of Materials Research has increased in size during the first half of the year (as you may have noticed) to serve more authors. Under the new Undergraduate Materials Research Initiative, 20 awards of $\$ 1,000$ each were made to undergraduate students to pursue original research over one year in 1999 (and 40 projects will be funded for 2000). Finally, a materials education outreach initiative, the Materials MicroWorld, is being developed to culminate in a traveling museum exhibit to begin circulating the United States in 2003.

If meetings and markets perform as expected, the Consolidated Budget will lose $\$ 0.02$ for every dollar of

Table 1

\begin{tabular}{|c|c|c|}
\hline \multicolumn{3}{|c|}{$\begin{array}{l}\text { MATERIALS RESEARCH SOCIETY } \\
\text { Statements of Activities (Income Statement) } \\
\text { Years Ended December 31, } 1998 \text { and } 1997\end{array}$} \\
\hline \multirow{3}{*}{$\begin{array}{l}\text { UNRESTRICTED NET ASSETS } \\
\text { Revenue, Gains and Other Support } \\
\text { Meeting and seminar registration }\end{array}$} & 1998 & 1997 \\
\hline & & \\
\hline & $\$ 1,883,509$ & $\$ 1,731,695$ \\
\hline Proceedings sales & $1,123,768$ & $1,086,193$ \\
\hline Subscriptions & 862,021 & 807,573 \\
\hline Membership dues & 373,402 & 377,968 \\
\hline Education & 28,448 & 28,515 \\
\hline Exhibit income & 567,743 & 569,938 \\
\hline Advertising & 461,199 & 418,184 \\
\hline Contributions & 89,049 & 93,882 \\
\hline Mailing list rental & 133,495 & 132,402 \\
\hline Miscellaneous income & 206,359 & 183,694 \\
\hline Federal financial assistance & 83,000 & 65,590 \\
\hline Other government funding & 55,136 & 130,963 \\
\hline \multirow{2}{*}{$\begin{array}{l}\text { Corporate funding of symposia } \\
\text { Investments: }\end{array}$} & 204,261 & 276,539 \\
\hline & & \\
\hline \multirow{3}{*}{$\begin{array}{l}\text { Investment income } \\
\text { Net unrealized gain on investments } \\
\text { Net realized gains on investments }\end{array}$} & 173,756 & 176,812 \\
\hline & 198,044 & 365,671 \\
\hline & 305,657 & 179,218 \\
\hline \multirow{2}{*}{$\begin{array}{l}\text { TOTAL REVENUE, GAINS, AND } \\
\text { OTHER SUPPORT }\end{array}$} & 677,457 & 721,701 \\
\hline & $6,748,847$ & $6,624,837$ \\
\hline \multicolumn{3}{|l|}{$\begin{array}{l}\text { Expenses: } \\
\text { Program Services }\end{array}$} \\
\hline Meetings & 984,920 & 934,551 \\
\hline Proceedings & 720,454 & 680,162 \\
\hline Subscriptions & 782,564 & 829,134 \\
\hline Membership & 416,119 & 380,446 \\
\hline Education & 23,113 & 20,252 \\
\hline Symposia & 199,707 & 233,945 \\
\hline Awards & 50,765 & 37,888 \\
\hline Supporting Services: & $3,177,642$ & $3,116,378$ \\
\hline Management and general & $3,190,232$ & $2,955,470$ \\
\hline TOTAL EXPENSES & $6,367,874$ & $6,071,848$ \\
\hline INCREASE IN NET ASSETS & 380,973 & 552,989 \\
\hline NET ASSETS AT BEGINNING OF YEAR & $5,542,531$ & $4,989,542$ \\
\hline NET ASSETS AT END OF YEAR & $\$ 5,923,504$ & $\$ 5,542,531$ \\
\hline
\end{tabular}

revenue; however, that loss would come on top of investments of over $\$ 0.82$ ( $\$ 4,863$ thousand at the end of 1998) built up over a number of years. Note that the 1999 budget is the first deficit Consolidated Budget passed by Council since 1990, and your Treasurer will be watching carefully to see whether the budget components meet their goals.

This report is my last as Treasurer. Merrilea Mayo (Pennsylvania State University) has assumed this office in September, after completing her term as the OSA/MRS Congressional Fellow. It has been my pleasure and honor to have served the Society and the members over the last two and a half years. I will continue to serve as an MRS volunteer, however, as I look forward to meetings in the Bahamas. In the meantime please send in your comments to ajhurd@sandia.gov.

Respectfully submitted,

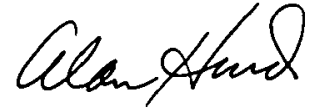

Alan Hurd, Treasurer (Interim)

Table II

MATERIALS RESEARCH SOCIETY
Statements of Financial Position (Balance Sheet)
December 31, 1998 and 1997

Current Assets:

ASSETS

Fixed Assets:

Land
Cash and cash equivalents

Investments, at fair value

Accounts receivable, net

Inventories, net

Government grants receivable

Prepaid expenses

Accrued interest receivable

TOTAL CURRENT ASSETS

Building

Data processing equipment and software

Furniture and office equipment

1998

$\$ 1,218,247$

$4,863,224$

647,628

252,310

16,050

94,504

29,982

$7,121,945$

329,013

$1,868,701$

$1,218,783$

470,264

$3,886,761$

$1,230,354$

Less: accumulated depreciation

$2,656,407$

TOTAL ASSETS $\begin{array}{r}1997 \\ \hline \$ 1,343,969 \\ 4,263,869 \\ 653,025 \\ 222,291 \\ 20,647 \\ 84,458 \\ 28,808 \\ \hline 6,617,067 \\ \hline\end{array}$

329,013

$1,826,525$

994,957

361,030

$3,511,525$

951,054

$2,560,471$

$\$ 9,177,538$

\section{Current Liabilities:}

\section{LIABILITIES AND NET ASSETS}

Current portion of long-term debt

Accounts payable and accrued expenses

Withheld and accrued payroll taxes

Accrued retirement plan contribution

Deferred revenues

TOTAL CURRENT LIABILITIES

Long-Term Debt

TOTAL LIABILITIES

Net Assets:

Unrestricted

Permanently restricted

TOTAL NET ASSETS

$\$ 150,000$

687,426

4,768

29,731

945,423

$1,817,348$

$2,037,500$

$3,854,848$

$\$ 45,030$

575,194

903

30,219

943,437

$1,594,783$

$2,040,224$

$3,635,007$

TOTAL LIABILITIES AND NET ASSETS
$5,835,049$

88,455

$5,923,504$

$\$ 9,778,352$ 